\title{
Expression of Matrix Metalloproteinases-8 and Myeloperoxidase in Pulp Tissue after Pulpotomy with Calcium Silicate Cements
}

Nayara Nery de Oliveira Cunha ${ }^{1}\left[\right.$, Marina Azevedo Junqueira ${ }^{1}\left(\mathbb{D}\right.$, Leopoldo Cosme-Silva ${ }^{\circledR}$, Laís da Silveira Terra Santos ${ }^{1}\left(\mathbb{D}\right.$, George Augusto Veloso de Oliveira ${ }^{3}{ }^{(}$, Rafael Tobias Moretti Neto ${ }^{4}$, Denismar Alves Nogueira ${ }^{5}$, Maísa Ribeiro Pereira Lima Brigagão ${ }^{3}$, Ana Beatriz da Silveira Moretti ${ }^{+(1)}$

\footnotetext{
${ }^{1}$ Department of Clinics and Surgery, School of Dentistry, Federal University of Alfenas, Alfenas, MG, Brazil.

${ }^{2}$ Department of Endodontics, School of Dentistry, Federal University of Alagoas, Maceió, AL, Brazil.

${ }^{3}$ Department of Biochemistry, Institute of Biomedical Sciences, Federal University of Alfenas, Alfenas, MG, Brazil.

${ }^{4}$ Department of Clinic and Surgery, Federal University of Alfenas, Alfenas, MG, Brazil.

${ }^{5}$ Department of Statistic, Institute of Exact Sciences, Federal University of Alfenas, Alfenas, MG, Brazil.
}

Correspondence: Prof. Dr. Ana Beatriz Silveira Moretti, Department of Clinics and Surgery, Federal University of Alfenas, Rua Gabriel Monteiro da Silva, 700, Alfenas, MG, Brazil. 37130-001. E-mail: ana.moretti@unifal-mg.edu.br

Academic Editor: Mohammad Khursheed Alam

Received: 25 May 2020 / Review: 02 September 2020 / Accepted: 05 October 2020

How to cite: Cunha NNO, Junqueira MA, Cosme-Silva L, Santos LST, Oliveira GAV, Moretti Neto RT, et al. Expression of matrix metalloproteinases-8 and myeloperoxidase in pulp tissue after pulpotomy with calcium silicate cements. Pesqui Bras Odontopediatria Clín Integr. 2021; 2 1:e0106. https://doi.org/10.1590/pboci.2021.038

\begin{abstract}
Objective: To evaluate the pulp tissue of rat molars after pulpotomies with mineral trioxide aggregate (MTA), Biodentine ${ }^{\mathrm{TM}}$ (BDT) and calcium hydroxide $(\mathrm{CH})$ mixed with sterile saline solution (24 hours, 72 hours, 7 days and 15 days), through correlating MPO activity with active neutrophils and MMP8 activity with tissue remodeling. Material and Methods: Thirty-eight Wistar rats were randomly distributed into groups (control, I (MTA gray), II (BDT), and III (CH)) and subdivided according to the study period of 24 hours, 72 hours, 7 days or 15 days after pulpotomy. MMP8 activity was assessed through fluorescence technique, and MPO activity was determined using the MPO assay. Results: A gradual decrease of MPO and MM8 activity occurred in the group MTA over the experimental periods $(\mathrm{p}<0.05)$. Groups BDT and $\mathrm{CH}$ exhibited an increase in the activity at 7 and 15 days $(\mathrm{p}<0.05)$. Conclusion: MTA demonstrated a decrease in the values of MPO e MMP8. BDT and CH showed high neutrophilic and collagenase activity over the experimental periods.
\end{abstract}

Keywords: Biocompatible Materials; Dental Pulp; Dental Pulp Capping; Pulpotomy; Peroxidase. 


\section{Introduction}

After pulpotomy, a biocompatible and bioactive material should protect the remaining vital pulp [14]. Calcium hydroxide (CH), Mineral trioxide aggregate (MTA) and, more recently, Biodentine ${ }^{\mathrm{TM}}$ (BDT) are biomaterials indicated for pulpotomy [1-3,5]. MTA exhibits faster pulp tissue healing and formation of mineralized tissue [3,5-7]. However, a disadvantage of MTA includes the high cost [8,9]. CH has demonstrated the formation of dentin bridge, but it was irregular [3,10,11]. In addition, limited areas of coagulative necrosis are commonly seen after $\mathrm{CH}$ use $[7,12]$. Biodentine ${ }^{\mathrm{TM}}$ (BDT) shows higher mechanical and handling properties than MTA [10,13].

The innate, non-specific immune response of the pulp tissue to pulpotomy materials results in an inflammatory process that aims to minimize the consequences of cell injury [14]. This immune response will occur through chemical mediators, immune and inflammatory cells. Pulp inflammation begins with the invasion of neutrophils, followed by tissue necrosis through the formation of microabscesses, which leads to the decomposition of the pulp tissue $[15,16]$.

Neutrophil marker proteins to evaluate pulpal tissue seem to be a promising approach because the amount of these cells is positively correlated with the state of pulpal inflammation. Among these proteins are the Matrix metalloproteinases (MMPs), such as the Matrix Metalloproteinase-8 (MMP8) [15-17], which is related to the extracellular matrix remodeling components and Myeloperoxidase (MPO), a valuable tool to assess degree of inflammation, representing the polymorphonuclear cell (PMN) activity in the tissues [18].

Long-term pulp response to pulpotomy materials has been studied [7,12]. However, initial reactions of capping materials on pulp tissue have not yet been explained [19]. Post-pulpotomy failures are believed to be associated with acute subclinical inflammatory reactions that can occur at any stage of pulp repair shortly after the procedure normally $[14,19,20]$. Thus, the objective of this study was to evaluate the activity of MPO (active neutrophils in the pulp) and MMP8 (tissue remodeling) in the pulp tissue of rats after pulpotomy using MTA, BDT and CH with physiological serum at 24 hours, 72 hours, 7 days and 15 days.

\section{Material and Methods}

Animals

The Institutional Ethics Committee approved the experimental protocol (protocol \#569/2014). Thirty-eight male rats aged 9 weeks (270-350g) were housed in polycarbonate cages and placed in a ventilated, temperature-controlled room. The animals were kept in a 12-hour light/dark cycle with temperature at $23^{\circ} \mathrm{C} \pm$ $1^{\circ} \mathrm{C}$. Commercial pellet diet and distilled water were available ad libitum. For the purpose of the study, the animals were randomly distributed into groups: I -MTA, II -BDT and III -CH, in order to allow comparisons at 4 different time points (24 hours, 72 hours, 7 days and 15 days). Two teeth of each animal (lower right and left first molars) were used (total $=74$ teeth), and each animal received one of the three treatments compared (Table 1). The total number of animals and the total number of teeth inserted in the procedure are in accordance with previous studies [21,22].

Table 1. Materials used and number of rats and teeth in each experimental group for the MPO and MMP8 tests.

\begin{tabular}{lccccc}
\hline \multicolumn{1}{c}{ Groups } & $\mathbf{2 4}$ hours & $\mathbf{7 2}$ hours & $\mathbf{7}$ days & $\mathbf{1 5}$ days & $\mathbf{N}$ \\
\hline I (MTA) & 3 rats/6 teeth & 3 rats/6 teeth & 3 rats/6 teeth & 3 rats/6 teeth & 12 rats/24 teeth \\
II (Biodentine) & 3 rats/6 teeth & 3 rats/6 teeth & 3 rats/6 teeth & 3 rats/6 teeth & 12 rats/24 teeth \\
III CH & 3 rats/6 teeth & 3 rats/6 teeth & 3 rats/6 teeth & 3 rats/6 teeth & 12 rats/24 teeth \\
\hline
\end{tabular}


Pulpotomy Procedure

The animals were anesthetized by intramuscular injection of a combination of ketamine $70 \mathrm{mg} / \mathrm{kg}$ (Rhobibarme Indústria Farmacêutica Ltda, Hortolândia, SP) and xylazine $6 \mathrm{mg} / \mathrm{kg}$ (Sespo Indústria e Comércio Ltda, Paulínia, SP, Brazil) and restrained on an operatory table, enabling their immobilization and maintaining open the mouths of the animals.

The pulpotomy technique was performed according to previous studies [9,23]. Pulp chamber was accessed initially by means of a 0.10-mm-diameter round diamond bur at high speed (no. 1011, KG Sorensen Indústria e Comércio Ltda., Barueri, SP, Brazil). The pulps were exposed with round steel bur (no. 1, Dentsply Indústria e Comércio Ltda, Petrópolis, RJ, Brazil), at 1500 rpm (Dforce 1000 Dentflex Industria e Comércio Ltda, Ribeirão Preto, SP, Brazil) always under saline irrigation, and the excess was removed with the aid of sterile disposable tips (Microbrush, KG Sorensen Indústria e Comércio Ltda., Barueri, SP, Brazil). The coronal pulp tissue was removed to the root canal entrances using a sharp curette (no. 5, SS White Ltda, Juiz de Fora, MG, Brazil) [9,23].

In Group I, a paste obtained by mixing gray MTA powder (Ângelus, Londrina, PR, Brazil) with distilled water at 1:1 powder/liquid ratio, according to the manufacturer's specifications, was placed into the root canal entrance in contact with the remaining dental pulp tissue. In Group II, the remaining pulp tissue was dressed with Biodentine (Septodont, St Maur des Fossés, France) mixed according to manufacturer's instructions. In Group III, the remaining pulp tissue was dressed with a paste obtained by mixing calcium hydroxide P.A. (Biodinâmica Química e Farmacêutica Ltda., Ibiporã, PR, Brazil) with distilled water at 1:1 powder/liquid ratio. All cavities were restored with resin-modified glass ionomer cement (Vitremer ${ }^{\circledR}, 3 \mathrm{M}$ ESPE, Sumaré, SP, Brazil).

The animals were anesthetized at the post-pulpotomy periods (24 hours, 72 hours, 7 days and 15 days), the radicular pulp that was in contact with the capping material was removed with dentin excavators (no. 5, SS White Ltda, Juiz de Fora, MG, Brazil), and then the animals were euthanized with an overdose of the anesthetic solution. In order to expand the operative field, all procedures were performed with the aid of a magnifying glass.

These pulp tissue samples were kept in falcon tubes with $1 \mathrm{~mL}$ of Tris buffer, previously prepared with 3.02 grams of Tris (Sigma Aldrich, St. Louis, USA), 5.85 grams of Sodium Chloride (Vetec Química Fina Ltda, Rio de Janeiro, RJ, Brazil) and 0.555g of Calcium Chloride (Aproquímica, Santa Maria, RS, Brazil), weighed on an analytical scale (Kern, Barlingen-Frommern, Germany). The reagent solutions were placed in beakers containing $250 \mathrm{ml}$ of Mili-Q water (Merck KGaA, Darmstadt, Germany). After the dilution, pH was corrected to 7.5 through a $\mathrm{pH}$ meter (Digimed, Campo Grande, MS, Brazil) and the volume corrected to $500 \mathrm{~mL}$.

\section{MPO assay (24 hours, 72 hours, 7 days and 15 days)}

For the assessment of MPO activity, the parameters previously described by Pulli et al. [24] were employed, by the peroxidase reaction of tissue with $\mathrm{H}_{2} \mathrm{O}_{2}$, using TMB as the chromogenic substrate. The collected tissue was homogenized using the Ultra 80 ultrasound machine (Ultra Stirrer). Inside an Eppendorf tube, it was added $350 \mu \mathrm{l}$ of 3,3',5,5'-tetramethylbenzidine solution (TMB 2.9 mM) to DMSO at 14.5\% (SigmaAldrich, St. Louis), $250 \mu \mathrm{l}$ of $\mathrm{H}_{2} \mathrm{O}_{2}$ at $0.75 \mathrm{mM}$ (Sigma-Aldrich, St. Louis), $50 \mu \mathrm{l}$ of sodium phosphate buffer solution $(150 \mathrm{mM}$ at $\mathrm{pH} 5.4)$ and $200 \mu \mathrm{l}$ of the sample. For 10 minutes, this mixture was incubated in a water bath at $37^{\circ} \mathrm{C}$, and the reaction was stopped by adding $50 \mu \mathrm{L}$ of $\mathrm{H}_{2} \mathrm{SO}_{4}$ at $2 \mathrm{M}$ (Sigma-Aldrich, St. Louis). The solution was dispensed in a quartz bucket and the absorbance measured at $450 \mathrm{~nm}$ with the aid of a spectrophotometer (Biochrom Libra S21/S22, Biochrom, Cambridge) to estimate MPO activity [24]. All tests 
were performed in triplicate. A standard curve was generated using human neutrophils (PMNs) isolated from blood by density-gradient centrifugation and suspended to $1 \times 10^{6}$ cells per milliliter in PBS. The absorbance value of the homogenate was evaluated by comparing them to the standard curve, which allowed finding the neutrophil concentration $(\mathrm{cell} / \mu \mathrm{L})$ of the sample since standardization by weighing was impossible. The absorbance of the pulp samples was compared with that of a dilution series of bovine serum albumin (BSA) using the Bradford method [20] to standardize the data according to the MPO amount (MPO per protein).

\section{MMP8 assay (24 hours, 72 hours, 7 days and 15 days)}

The MMP8 activity was determined in the pulp tissue homogenate through fluorescence technique. $360 \mu \mathrm{l}$ of the homogenate were collected and added to $360 \mu \mathrm{l}$ of Tris- $\mathrm{HCl}$ buffer solution $(\mathrm{pH} 7.5)$ at $4{ }^{\circ} \mathrm{C}$ with $50 \mathrm{mM}$ of Zinc Sulfate (Merck KGaA, Darmstadt, Germany) and 0.05\% polyethylene glycol (Sigma Aldrich, St. Louis, USA) inside a quartz bucket. Then, the solution was taken to the same fluorometer (Varian, Mulgrave, Victoria, Australia) and $80 \mu \mathrm{l}$ of MMP8 substrate at $200 \mu \mathrm{M}$ (Sigma-Aldrich, St. Louis, USA) [24] were added. The following parameters were used in the fluorometer (Varian, Mulgrave, Victoria, Australia): $280 \mathrm{~nm}$ of excitation and $360 \mathrm{~nm}$ of emission. The enzymatic kinetics was evaluated at $0,15,30,60,75,90120,135,150$ and 180 minutes. MMP8 determination was performed in quintuplicate, and the mean was used to compare BSA dilutions (MMP8 per protein). All the pulpotomies, as well as tests for MPO and MMP8 were performed by the same operator. However, the analyzes of the tests were carried out by another researcher.

Statistical Analysis

A factorial design was used with two factors: period (24 hours, 72 hours, 7 days and 15 days) and treatment (MTA, BDT, CH), through three repetitions. The results were analyzed by the Shapiro Wilk test to evaluate the normal distribution. The mean values were statistically analyzed by Tukey test. MPO and MMP 8 data were correlated through Pearson test. The level of significance was set at $5 \%(\mathrm{p}<0.05)$.

\section{Results}

The MPO activity was used as a parameter for neutrophilic activity. All tested materials induced significantly higher MPO activity than that of the control. The statistical analysis of the variable treatment at each study period revealed a statistically significant value at 24 hours, which indicated that BDT showed the lowest MPO activity (0). At 7 days, CH exhibited the highest MPO activity (0.0191), and at 15 days MTA presented the lowest MPO activity (0.0422) (Figure 1-A).

The statistical results of the variable period for each treatment revealed statistically significant differences over time. The square adjustment of the polynomial regression models was chosen and showed that MTA, BDT and CH had 86.95\% (0), 99.99\% (0.0011) and 24.60\% (0.0007) of confidence, respectively (Figure $1-\mathrm{B})$.

MMP8 activity was used as a tissue-remodeling marker. All tested materials induced MMP8 activity significantly higher than that of the control. The statistical analysis of the variable treatment revealed that at 24 hours, the result was highly significant, indicating that BDT showed the lowest MMP8 activity (0). At 72 hours, BDT (0) was statistically similar to $\mathrm{CH}$, exhibiting the lowest MMP8 activity. At 7 days, BDT exhibited the highest MMP8 activity (0.0004) and, at 15 days, MTA presented the lowest MMP8 activity (0.017) (Figure 2-A)

The statistical results of the variable period for each treatment revealed statistically significant differences over time. The square adjustment of the polynomial regression models was chosen and showed that MTA, BDT and CH had $98.85 \%(0), 89.82 \%(0)$ and $23.02 \%(0)$ of confidence, respectively (Figure 2-B). 

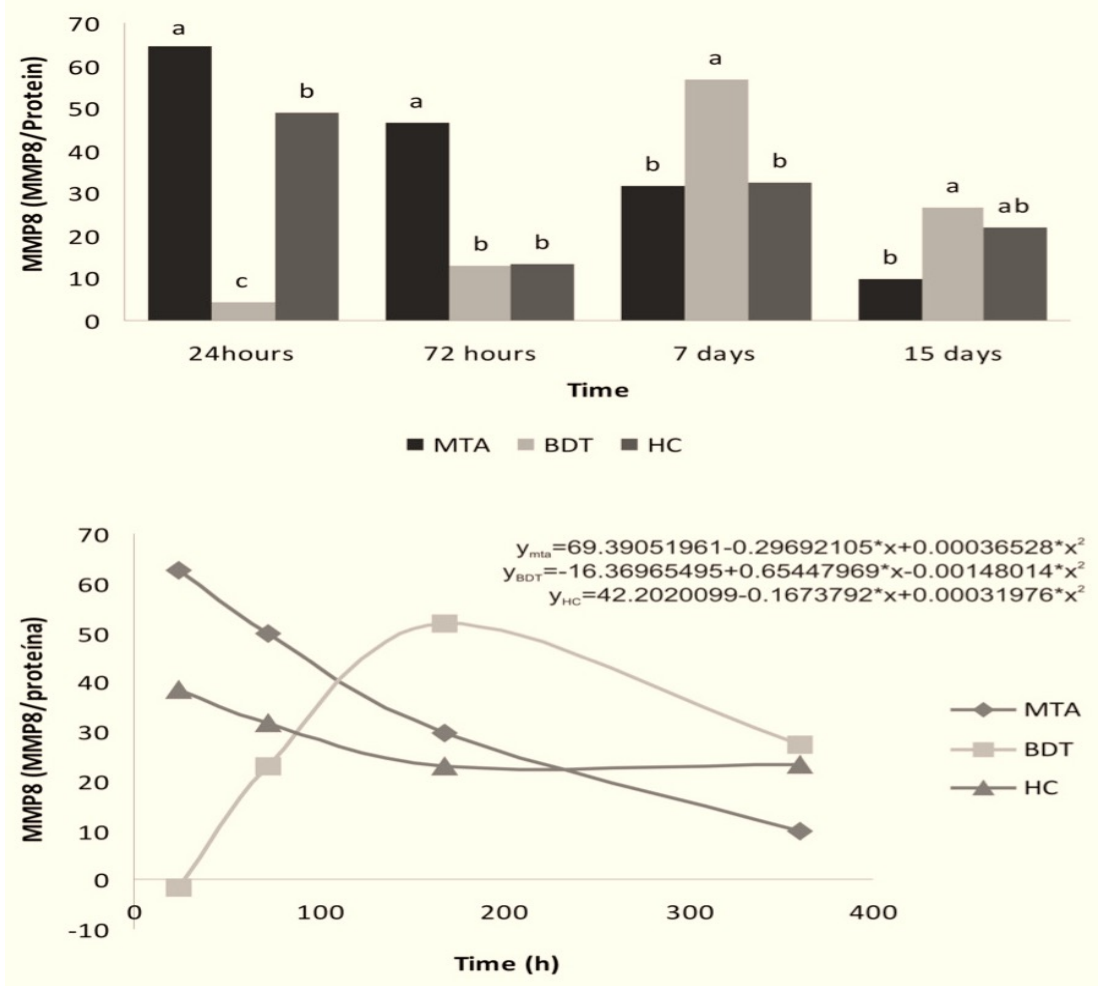

Figure 1. MMP8/protein activity (A) of the treatments over the experimental periods. Groups with similar letters do not differ statistically. (B) Functions of the linear regression adjusted as per the variable period for each treatment of MMP8/protein activity.
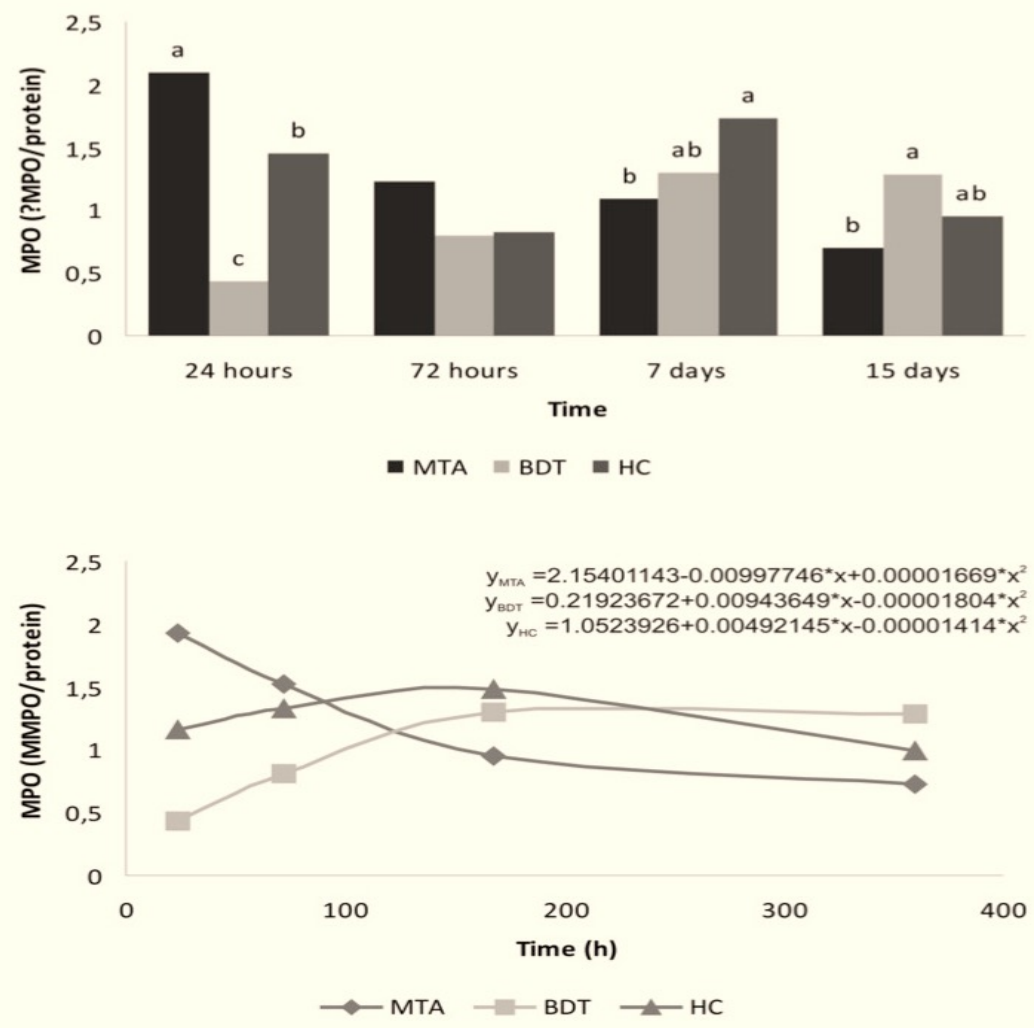

Figure 2. MPO/protein activity (A) of the treatments over the experimental periods. Groups with similar letters do not differ statistically. (B) Functions of the linear regression adjusted as per the variable period for each treatment of $\mathrm{MPO} /$ protein activity. 


\section{Discussion}

The present study correlates the pulp tissue's inflammatory response to its healing capacity [20]. Endodontic materials used in pulpotomy are in intimate contact with the remaining vital tissue and clinically biomaterials should be as biocompatible as possible and thereby avoid damage to the pulp tissue. Understanding the interaction between the pulpotomy material and the pulp tissue is important to determine how the tissue was injured and how it will be repaired/regenerated [25].

Experimental studies in rats estimate 30 days of human life for each day of the animal's life [26]. Given this fact, as our study sought to estimate possible pulp changes early on, working with rats was essential since 24 hours for a mouse is equivalent to 30 days for humans, 72 hours for 3 months and 15 days for 15 months. In humans, it would be unfeasible because we could not simply remove treated teeth at these stipulated times.

Despite advancements in understanding the biological and molecular events controlling materials used in pulpotomy as MTA, BDT and $\mathrm{CH}$ action the pulp healing mechanism is still unknown. This study confirmed the presence of inflammation through MPO and MMP8 activity after pulpotomy with the tested materials expressing higher values than that of the control, indicating the pulpotomy material caused the inflammatory reaction. Failures of pulpotomies may be associated with acute inflammatory reactions in the initial post-operative periods [27,28].

In this study, the biochemical test to evaluate neutrophilic activity (MPO) was chosen since it avoids the problems and limitations of the histological technique requiring the inspection of multiple serial cuts, as the neutrophil distribution in the tissue is heterogeneous [18]. Additionally, this technique can distinguish whether the neutrophils do or do not have activity, that is, few active neutrophils have a greater influence on the inflammatory response than many inactive neutrophils.

The inflammatory process is related to bio-remineralization and tissue remodeling. MMP8 in inflammatory lesions comes mainly from PMNs (neutrophils) $[15,16]$. High MMP8 values indicate increased degradation of type 1 collagen (the main MMP8 substrate) [16], which is the scaffold for calcium phosphate deposition [20], thus preventing the formation of mineral crystals. Therefore, knowing the factors regulating MMP synthesis and secretion in inflamed pulp tissue is relevant $[15,16]$. In the present study, the substrates were marked by fluorophores, which are beneficial to monitor MMP activity in real-time without stopping the reaction [29]. The increase in fluorescence is directly related to the degree of substrate degradation. In addition, MMP8 activity demonstrates higher sensitivity than conventional ELISA [16].

We showed that MTA's initial inflammatory response is characterized by intense neutrophil activity and tissue remodeling at 24 and 72 hours. Previous studies applying other methodologies demonstrated the presence of neutrophils in contact with MTA [20], which has been attributed to the higher initial pH values because of $\mathrm{CH}$ formation during MTA hydration, thus inducing the release of inflammatory cytokines $[8,14,30]$. In this study at 7 days, MTA exhibited the lowest MPO and MMP8 activity, indicating potential healing activity and formation of mineralized tissue. During the maturation process, calcium-deficient hydroxyapatite is formed on the MTA surface. Consequently, the available $\mathrm{CH}$ amount decreases, reducing the $\mathrm{pH}$ values and the inflammatory response [19,20,31].

MPO and MMP8 activity for group BDT was smaller than that for the other materials at 24 hours and continued to be lower at 72 hours. Although BDT and MTA have similar bioactivity, the initial difference of MMP8 and MPO activity among groups could be justified by the smaller initial pH of BDT than that of MTA [30,32]; thus, BDT induces a smaller release of inflammatory cytokines, neutrophilic activity and 
collagenases than MTA. At 15 days, BDT exhibited higher MPO and MMP8 activity, similar to that of $\mathrm{CH}$, demonstrated by an increase of the late inflammatory process. Mild inflammation at 7 days was found with BDT, probably because of the calcium release during the healing process by promoting longer irritating effects on pulp tissues [3,33]. Han and Okiji [31] showed a higher release of calcium ions by BDT than MTA when immersed in distilled water at 7 days with a peak value at 14 days [32], resulting in pH increase, greater release of inflammatory cytokines [3,9,32] and MPO/MMP8 activity. This fact may explain that the increase of MMP 8 activity caused by BDT promoted a higher degradation of type 1 collagen resulting in less formation of mineralized tissue, which starts during the acute phase of inflammation [20].

MPO and MMP8 activity of group $\mathrm{CH}$ were numerically intermediate in relation to the other materials for all experimental periods, demonstrating its longer irritating potential and chronicity of the inflammatory process and delaying pulp tissue healing. We believe that due to its low solubility [11], CH has a longer irritating effect by the constant release of calcium and hydroxyl ions [9,33], which results in an unpredictable response to the material [3]. The mechanism of action of calcium hydroxide in pulp repair is attributed to its alkaline pH11 that stimulates MPO and MMP8 enzymatic activity. In this study, we observed intense neutrophilic activity at 7 days, indicating the persistent necrosis in the group $\mathrm{CH}[7,10-12]$. This delays the pulp healing, acting as a foreign body and inducing marked inflammation of pulp tissue. We believe that the failure of pulpotomies with calcium hydroxide is not related to pre-existing pulp inflammation but to the material's irritating potential.

Although the observation periods are relatively short, this study brought the biochemical test as a new vision for assessing neutrophilic activity. This technique can distinguish whether or not neutrophils have activity, that is, few active neutrophils have a greater influence on the inflammatory response than many inactive neutrophils [15-18]. The present study provides important information about the activity of MPO and MMP8 in the pulp tissue of rats after pulpotomy with different biomaterials. The results in animals represent an initial analysis $[2,4,9,34]$ and is an essential step to study the biological mechanisms of pulp tissue after pulpotomy. Although promising results have been reported in this study, it is important to remember that findings cannot be generalized since they are a dependent experimental model. In this way, new studies are essential for exploring the inflammatory mechanisms involved in pulpotomy.

\section{Conclusion}

MTA demonstrated a decrease in the values of MPO e MMP8, indicating potential healing activity in pulp tissue. BDT and $\mathrm{CH}$ showed high neutrophilic and collagenase activity over the experimental periods, indicating increased irritating potential, and delaying the healing process. From the results obtained, MTA proved to be the most suitable material for pulpotomies.

\section{Authors' Contributions}

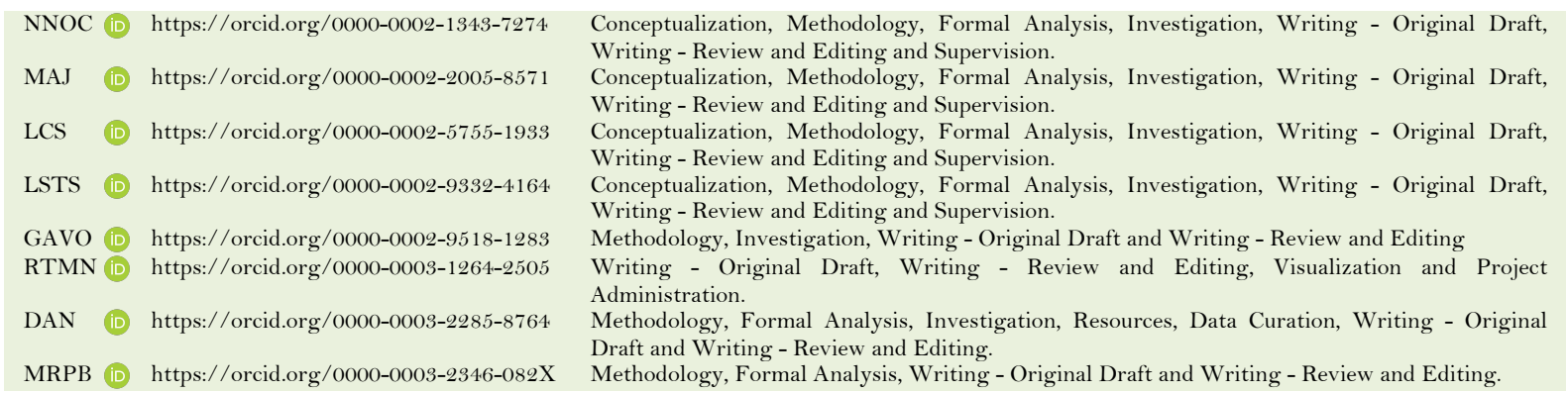


ABSM (D) https://orcid.org/0000-0002-9953-6010 Conceptualization, Methodology, Formal Analysis, Investigation, Resources, Writing - Original Draft, Writing - Review and Editing, Supervision and Project Administration.

All authors declare that they contributed to critical review of intellectual content and approval of the final version to be published.

\section{Financial Support}

None.

\section{Conflict of Interest}

The authors declare no conflicts of interest.

\section{Data Availability}

The data used to support the findings of this study can be made available upon request to the corresponding author.

\section{References}

[1] Junqueira MA, Cunha NNO, Caixeta FF, Marques NCT, Oliveira TM, Moretti ABS, et al. Clinical, radiographic and histological evaluation of primary teeth pulpotomy using MTA and ferric sulfate. Braz Dent J 2018; 29(2):159-65. https://doi.org/10.1590/0103-6440201801659

[2] Zaen El-Din AM, Hamama HH, Abo El-Elaa MA, Grawish ME, Mahmoud SH, Neelakantan P. The effect of four materials on direct pulp capping: An animal study. Aust Endod J 2020; 46(2):249-56. https://doi.org/10.1111/aej.12400

[3] Nosrat A, Peimani A, Asgary S. A preliminary report on histological outcome of pulpotomy with endodontic biomaterials vs calcium hydroxide. Restor Dent Endod 2013; 38(4):227-33. https://doi.org/10.5395/rde.2013.38.4.227

[4] Cosme-Silva L, Gomes-Filho JE, Benetti F, Dal-Fabbro R, Sakai VT, Cintra LTA, et al. Biocompatibility and immunohistochemical evaluation of a new calcium silicate-based cement, Bio-C Pulpo. Int Endod J 2019; 52(5):689700. https://doi.org/10.1111/iej.13052

[5] Torabinejad M, Parirokh M. Mineral trioxide aggregate: a comprehensive literature review--part II: leakage and biocompatibility investigations. J Endod 2010; 36(2):190-202. https://doi.org/10.1016/j.joen.2009.09.010

[6] Nosrat A, Seifi A, Asgary S. Regenerative endodontic treatment (revascularization) for necrotic immature permanent molars: a review and report of two cases with a new biomaterial. J Endod 2011; 37(4):562-7. https://doi.org/10.1016/j.joen.2011.01.011

[7] Oliveira TM, Moretti AB, Sakai VT, Lourenço Neto N, Santos CF, Machado MA, et al. Clinical, radiographic and histologic analysis of the effects of pulp capping materials used in pulpotomies of human primary teeth. Eur Arch Paediatr Dent 2013; 14(2):65-71. https://doi.org/10.1007/s40368-013-0015-x

[8] Darvell BW, Wu RCT. "MTA"-an Hydraulic Silicate Cement: review update and setting reaction. Dent Mater 2011; 27(5):407-22.

[9] De Rossi A, Silva LA, Gatón-Hernández P, Sousa-Neto MD, Nelson-Filho P, Silva RA, et al. Comparison of pulpal responses to pulpotomy and pulp capping with biodentine and mineral trioxide aggregate in dogs. J Endod 2014; 40(9):1362-9. https://doi.org/10.1016/j.joen.2014.02.006

[10] Villat C, Tran XV, Pradelle-Plasse N, Ponthiaux P, Wenger F, Grosgogeat B, et al. Impedance methodology: A new way to characterize the setting reaction of dental cements. Dent Mater 2010; 26(12):1127-32. https://doi.org/10.1016/j.dental.2010.07.013

[11] Mohammadi Z, Dummer PM. Properties and applications of calcium hydroxide in endodontics and dental traumatology. Int Endod J 201 1; 44(8):697-730. https://doi.org/10.1111/j.1365-2591.2011.01886.x

[12] Huth KC, Hajek-Al-Khatar N, Wolf P, Ilie N, Hickel R, Paschos E. Long-term effectiveness of four pulpotomy techniques: 3-year randomised controlled trial. Clin Oral Investig 2012; 16(4):1243-50. https://doi.org/10.1007/s00784-01 1-0602-3

[13] Araújo LB, Cosme-Silva L, Fernandes AP, Oliveira TM, Cavalcanti BN, Gomes Filho JE, et al. Effects of mineral trioxide aggregate, Biodentine ${ }^{\mathrm{TM}}$ and calcium hydroxide on viability, proliferation, migration and differentiation of stem cells from human exfoliated deciduous teeth. J Appl Oral Sci 2018; 26:e20160629. https://doi.org/10.1590/1678-7757-2016-0629

[14] Reyes-Carmona JF, Santos AR, Figueiredo CP, Felippe MS, Felippe WT, Cordeiro MM. In vivo host interactions with mineral trioxide aggregate and calcium hydroxide: inflammatory molecular signaling assessment. J Endod 2011; 37(9):1225-35. https://doi.org/10.1016/j.joen.2011.05.031

[15] Hannas AR, Pereira JC, Granjeiro JM, Tjäderhane L. The role of matrix metalloproteinases in the oral environment. Acta Odontol Scand 2007; 65(1):1-13. https://doi.org/10.1080/00016350600963640

[16] Zehnder M, Wegehaupt FJ, Attin T. A first study on the usefulness of matrix metalloproteinase 9 from dentinal fluid to indicate pulp inflammation. J Endod 2011; 37(1):17-20. https://doi.org/10.1016/j.joen.2010.10.003 
[17] Birkedal-Hansen H. Role of Matrix Metalloproteinases in Human Periodontal Diseases. J Periodontol 1993; 64(5 Suppl):474-84. https://doi.org/10.1902/jop.1993.64.5s.474

[18] Accorsi-Mendonça T, Silva EJ, Marcaccini AM, Gerlach RF, Duarte KM, Pardo AP, et al. Evaluation of gelatinases, tissue inhibitor of matrix metalloproteinase-2, and myeloperoxidase protein in healthy and inflamed human dental pulp tissue. J Endod 2013; 39(7):879-82. https://doi.org/10.1016/j.joen.2012.11.011

[19] Shahi S, Rahimi S, Yavari HR, Mokhtari H, Roshangar L, Abasi MM, et al. Effect of mineral trioxide aggregates and Portland cements on inflammatory cells. J Endod 2010; 36(5):899-903. https://doi.org/10.1016/j.joen.2010.01.001

[20] Reyes-Carmona JF, Santos AS, Figueiredo CP, Baggio CH, Felippe MC, Felippe WT, et al. Host-mineral trioxide aggregate inflammatory molecular signaling and biomineralization ability. J Endod 2010; 36(8):1347-53. https://doi.org/10.1016/j.joen.2010.04.029

[21] Takei E, Shigetani Y, Yoshiba K, Hinata G, Yoshiba N, Okiji T. Initial transient accumulation of M2 macrophageassociated molecule-expressing cells after pulpotomy with mineral trioxide aggregate in rat molars. J Endod 2014; 4O(12):1983-8. https://doi.org/10.1016/j.joen.2014.08.012

[22] Esmeraldo MR, Carvalho MGF, Carvalho RA, Lima RF, Costa EMMB. Inflammatory effect of green propolis on dental pulp in rats. Braz Oral Res 2013; 27(5):417-22. https://doi.org/10.1590/S1806-83242013005000022

[23] Lopes CS, Junqueira MA, Cosme-Silva L, Pegoraro COR, Garbelini CCD, Oliveira TM, et al. Initial inflammatory response after the pulpotomy of rat molars with MTA or ferric sulfate. J Appl Oral Sci 2019; 27:e20180550. https://doi.org/10.1590/1678-7757-2018-0550

[24] Pulli B, Ali M, Forghani R, Schob S, Hsieh KL, Wojtkiewicz G, et al. Measuring myeloperoxidase activity in biological samples. PLoS One 2013; 8(7):e67976. https://doi.org/10.1371/journal.pone.0067976

[25] Ferracane JL, Cooper PR, Smith AJ. Can interaction of materials with the dentin-pulp complex contribute to dentin regeneration? Odontology 2010; 98(1):2-14. https://doi.org/10.1007/s 10266-009-0116-5

[26] Andreollo NA, Santos EF, Araújo MR, Lopes LR. Rat's age versus human's age: what is the relationship? Arq Bras Cir Dig 2012; 25(1):49-51. https://doi.org/10.1590/s0102-67202012000100011

[27] Gomes ACG, Filho JEG, de Oliveira SH. MTA-induced neutrophil recruitment: a mechanism dependent on IL-1beta, MIP-2, and LTB4. Oral Surg Oral Med Oral Pathol Oral Radiol Endod 2008; 106(3):450-6. https://doi.org/10.1016/j.tripleo.2008.03.022

[28] Kramer PR, Woodmansey KF, White R, Primus CM, Opperman LA. Capping a pulpotomy with calcium aluminosilicate cement: comparison to mineral trioxide aggregates. J Endod 2014; 40(9):1429-34. https://doi.org/10.1016/j.joen.2014.02.001

[29] Kupai K, Szucs G, Cseh S, Hajdu I, Csonka C, Csont T, et al. Matrix metalloproteinase activity assays: Importance of zymography. J Pharmacol Toxicol Methods 2010; 61(2):205-9. https://doi.org/10.1016/j.vascn.2010.02.011

[30] Rajasekharan S, Martens LC, Cauwels RG, Anthonappa RP. Biodentine ${ }^{\mathrm{TM}}$ material characteristics and clinical applications: a review of the literature. Eur Arch Paediatr Dent 2018; 19(1):1-22. https://doi.org/10.1007/s40368-018-0328-x

[31] Han L, Okiji T. Uptake of calcium and silicon released from calcium silicate-based endodontic materials into root canal dentine. Int Endod J 2011; 44(12):1081-7. https://doi.org/10.1111/j.1365-2591.2011.01924.x

[32] Grech L, Mallia B, Camilleri J. Investigation of the physical properties of tricalcium silicate cement-based root-end filling materials. Dent Mater 2013; 29(2):e20-8. https://doi.org/10.1016/j.dental.2012.11.007

[33] Camilleri J. Characterization of hydration products of mineral trioxide aggregate. Int Endod J 2008; 41(5):408-17. https://doi.org/10.1111/j.1365-2591.2007.01370.x

[34] Cosme-Silva L, Santos AF, Lopes CS, Dal-Fabbro R, Benetti F, Gomes-Filho JE, et al. Cytotoxicity, inflammation, biomineralization, and immunoexpression of IL- $1 \beta$ and TNF- $\alpha$ promoted by a new bioceramic cement. J Appl Oral Sci 2020; 28:e20200033. https://doi.org/10.1590/1678-7757-2020-0033 